\title{
Te Kooti Arikirangi Te Turuki, c.1832-17 April 1893
}

\author{
Judith Binney
}

Te Kooti Arikirangi has been remembered primarily as a warrior and prophetic leader. But he should be as well known as a composer of waiata (songs), along with the texts and sayings of the Ringatū church, which he founded. He is famous for the unique painted and carved Māori meetinghouses that he created in the later nineteenth century to teach history and to bring into existence a new Māori visual language of symbols. At the end of the New Zealand wars 1860-1872, Te Kooti carried his message of peace to Māori communities. As the greatest of the Māori guerrilla fighters, he became (along with Te Whiti-o-Rongomai, whose teachings he eschewed), the most influential of the prophets of peace and reconciliation. At the same time, he warned Māori - through his waiata and predictive statements - of abuses of law by which most of their land would be taken in the later nineteenth century. It cannot be said that he was wrong.

Until recent times, Te Kooti was excoriated in standard histories as a 'murderer' and a 'rebel without a cause'. He was singled out by the colonial armed forces and popular newspapers as a 'villainous' fighter, because he led attacks on civilian settlements, both Māori and settler communities. He was usually treated as a 'savage', cunning but irrational. The reasons for his actions, including his military strategies, were never assessed, and he bore the burdens of prejudice all his life. It is a tribute to the man that he rose above these condemnations to become a religious leader and advocate of peace and compassion.

Te Kooti was born about 1832 in the community of Te Pā-ō-Kahu on the shores of the coastal lagoon at Tūranganui (Poverty Bay). He was the second of four surviving children of Hōne Te Rangipātahi and Tūrākau (Hēni) of the Rongowhakaata iwi. His elder brother, Kōmene, remained a close intimate until Kōmene's death in battle in 1868. The children were born in a line of descent collateral with the senior chiefs of Ngāti Maru, a major hapu of Rongowhakaata, and in their youth were known as turbulent, potential leaders. However, Te Kooti was the more famous because of an early prediction associated with his birth: the seer, Toiroa, who lived on Mahia peninsula, foresaw the births of two (or three) children to close kinsmen. The sequence of their births foretold the future, for good or ill: if the first born, the child of Te Tūruki, died and the younger, the child of Te Rangipātahi, lived, 
then evil would stalk the land. Toiroa named that child Arikirangi, and dedicated him to the Māori god of war and humankind, Tū-matauenga. Toiroa's prediction for Arikirangi is dated 1766, three years before Captain James Cook's landfall at Tūranga. The first waiata recorded in Te Kooti's manuscript book of songs famously begins, 'Tiwha tiwha te pō' (Dark, dark is the night), and warns, 'Ko Arikirangi tenei ra te haere nei' (There is Arikirangi to come).

As well as his initial baptismal dedication to Tū, Te Kooti was educated by the Church Missionary Society mission at Tūranga, where he chose his Anglican baptismal name, Te Kooti. He was known under this name by April 1852; it was probably a transliteration of the English surname Coates, the lay secretary of the Society. Te Kooti was influenced by the missionary Rev. Thomas Grace, who thought highly of him. But Grace was transferred from the district in 1853, partly because of his radical views for establishing Māori economic independence from the early European traders, and Te Kooti fell out with his successor, Rev. William Williams. It was undoubtedly under Grace's influence that Te Kooti became the supercargo, the man in charge of commerce on a number of locally owned, Māori vessels that traded directly with Auckland, cutting out the Pākehā middlemen at Tūranga - and thereby earning their long-standing enmity.

The name Te Tūruki, by which Te Kooti later became known among his religious followers, notably those belonging to the Tūhoe tribe of the Urewera, was taken from the kinsman who reared him after his own father rejected him as a child, notoriously burying him in a kūmara (sweet potato) storage pit. Te Kooti adopted this name after his return from exile on Wharekauri (Chatham Island) in 1868, and it bore the implication of his spiritual rebirth.

As a young man, Te Kooti gained a reputation for his wildness but, equally, he associated with a group of men who challenged the early settlers, seeking agreed payments in compensation for informal land purchases. From the foundation of the colony in 1840 until 1865 individual settlers could not directly purchase Māori land, but at Poverty Bay a number of unofficial transactions took place, whose long-term validity depended on continuing good relations with the Māori sellers. Te Kooti objected to the illegal sale in 1843 of a block of Ngāti Maru land, in which he had rights, by one section of owners to the trader John Harris. This block, enlarged, later became known as 'Matawhero 4', and it was there that Te Kooti struck in November 1868, after his return from his unlawful imprisonment on Wharekauri since 1866, an exile that had been triggered by Harris's self-interested, whispering advice to the 
government. His attack on Matawhero, more than any other event, gained Te Kooti notoriety among the European settlers. The underlying land dispute was never acknowledged, and was historically buried by the decisions of the Poverty Bay Land Commission in 1869, when it granted the land directly to its later European purchaser, the monopolist George Read. Nor was the fact remembered that the majority of the Europeans whom Te Kooti killed were serving militia men and their families, who had come to live illegally on this land during Te Kooti's forced exile. The reasons for Te Kooti's actions were never acknowledged, while the deaths of thirty Europeans (including some part-Māori children) and about twenty-two Māori were shouted loud.

Te Kooti had been sent to Wharekauri in June 1866 as a political prisoner. That he was included among the exiled East Coast war-captives was a travesty of justice: he demanded a trial but never received one. He had been fingered as a 'spy' during the fighting at Tūranga in November 1865 when government forces invaded and attacked Pai Mārire refugees sheltering at Waerenga-ā-Hika pā (fortification). The refugees, followers of this new religion, had fled before the government's forces, called in by the Ngāti Porou tribe of the upper East Coast, and pursued as they fled south. Te Kooti fought alongside the government's troops at Waerenga-ā-Hika, as he opposed the teachings of the Pai Mārire pentecostalist faith, although he, like most other Māori leaders present, thought that the government assault was provocative, its purpose being to obtain land confiscation in reprisal for military resistance. The charge of spying collapsed, but in April 1866 Harris urged Te Kooti's rearrest, together with that of his brother, Kōmene, calling them 'known thieves' and cattle rustlers.

Te Kooti first developed his religious teachings on Wharekauri. He recorded them in his diary, written on the pages of a former policeman's notebook. After his recovery from what was, almost certainly, the heights of pulmonary tubercular fever, during which he experienced visions and heard the Voice ('Reo') of God speaking to him, he considered that he had been chosen to recover the people and the land. On 21 May 1867, the Voice told him that 'all the things I tell you of now may be set down in writing' ('kia tuhia nga korero katoa i korero nei ahau ki a koe'). From the beginning Te Kooti created written texts for the new, and soon rapidly growing religion. He and his followers identified themselves with the children of Israel, lost in their own land.

On Wharekauri, Te Kooti married Maata Te Ōwai, one of the female prisoners, in a legal ceremony conducted by the resident magistrate (and 
military commander). Prior to this marriage he had had a son by his first wife, Irihāpeti, daughter of Te Waaka Pūākanga, one of the chiefly co-owners of the Māori vessels on which Te Kooti had acted as supercargo. Te Kooti and Irihāpeti had one son, Wētini, born c.1860; neither she nor the child accompanied Te Kooti into exile. However, on 28 October 1866 a second son was born to Te Kooti on the island; neither the child's name nor that of his mother were recorded. On 27 July 1867, declaring himself a bachelor, Te Kooti married Maata, but soon in song he seemingly referred to her with scorn, 'a second wife, a hustler to the bed' ('he punarua he tutetute ki te moenga'). The marriage became sour shortly after their escape from the island in 1868.

Te Kooti organized and led the great escape of the prisoners - 163 men, sixty-four women and seventy-one children - on 4 July 1868 by capturing the supply ship Rifleman. The deed was planned with military precision, and was characterized by 'the moderation shown in the hour of victory', as G. S. Cooper wrote in his official report to the government. Only one guard died, killed against Te Kooti's instructions, in a vendetta. The whakarau (prisoners) landed at Whareongonga, a sheltered cove south of Tūranga, on 9 July 1868; from there they planned an inland trek to Tauranga village on Lake Taupō. This was the place that Te Kooti had determined to make his own, perhaps following the advice of one of the exiles and his greatest chiefly supporter, Te Rangitāhau, who came from the district.

But the whakarau were pursued because they were armed. Burdened with women and children and goods, their passage was slow. Three times they were ambushed by militia forces, sent by the resident magistrate at Tūranga, Reginald Biggs, and three times the whakarau outwitted their pursuers. After the third victory, at Ruakituri on 8 August, Te Kooti took sanctuary at Puketapu (Holy Mountain) on the borders of the Urewera country. Here he sought right of passage through the mountains from Tūhoe, and also support from the Māori King, Tāwhiao, himself living in sanctuary with the Ngāti Maniapoto tribe at Te Kuiti. Rejected by both, Te Kooti turned back and struck at Matawhero on 9 November 1868. There he killed Biggs, the agent of the government's land confiscation policies at Tūranga and his determined pursuer.

He also struck at those Māori whom he blamed for his unjust exile, notably the old chief Paratene Pōtoti, when he waited, unarmed, to negotiate with Te Kooti at Ōweta pā on 14 November. For this execution Te Kooti gained Māori enemies at Tūranga, and as he withdrew, on 17 November, he also took with him three hundred Māori prisoners. He hoped to convert them to his cause, 
and in this he was partly successful. One who joined him voluntarily at this time was Hēni Kumekume, who became his favourite wife. Hēni stayed with Te Kooti through the long years of war, lived with him during the days of peace, and died after him, in 1898.

After the attack on Matawhero, Te Kooti became a wanted man. Following the vicious siege at Ngātapa pā, 1-6 January 1869, a price was laid upon his head. Ngātapa was the first of Te Kooti's major military losses. Although he escaped with about fifty of the whakarau, scrambling down rough vine ropes at the rear of the pa, most of the rest who got away were captured and executed by the government's forces. These men were, as Major William Mair observed, largely 'unarmed Turanga natives who had been taken prisoner by Te Kooti'. One hundred and twenty were summarily shot, and of the remaining eighty prisoners left alive almost all were women and children.

The hunt for Te Kooti ranged through the central parts of the North Island the eastern and western parts of the Bay of Plenty, the Urewera, Ōpepe, Taupō, and Rotorua - and out to Mōhaka, Tolaga Bay (Uawa) and Nūhaka on the East Coast. He was never captured. Many supported him covertly, notably Tūhoe of the Urewera. At least four of his other wives joined him during this time: Ōriwia Nihipora Kunaiti (died 1931); Hūhana Tamati (Hūhana Whakarau) (c.1850-1898); Honia (Nia) Te Whiu; and Makurata Hineore (Makurata Himiona) (died c.1930). Hūhana and Ōriwia were both captured during the fighting and both returned to him, but later left. Makurata parted from him when he finally fled the Urewera in 1872 into sanctuary with Ngāti Maniapoto. It was Rewi Maniapoto's secret karanga (call) which found him the man who could not be found - and offered him shelter, if he came in peace. On 30 May 1872 the little group of battered refugees - two women (one of them Hēni Kumekume) and seven men - reached Te Kuiti and the Māori King. Rewi's call brought the New Zealand wars to an end.

It was during the years of shelter in the King Country, 1872-1883, that Te Kooti developed the early written texts of his faith into the body of doctrine and waiata that are used by the Ringatū. The name itself, meaning the 'Upraised Hand', was taken from the early practice of raising the right hand at the end of prayers in homage to God. In exile, Te Kooti developed the four 'pillars' of the Ringatū year, 1 January and 1 July, together with the huamata (planting) (usually held on 1 June) and the pure (harvest) (celebrated variously on 1 November or 1 December depending on the region). The sacred day of each month, the Twelfth, was formally instituted in 1888. 
Te Kooti was pardoned in February 1883. From this date, he was ostensibly free to travel, and he began his many journeys to Māori communities, including those that had fought against him. As one Māori elder recalled, 'wherever Te Kooti went - wherever he step foot from one area to another - he's singing'. Te Kooti composed a favourite waiata in 1887 in response to his first invitation from Te Whānau-a-Apanui, a tribe who had fought against him, to visit. Sung on the journey to Maraenui, it commences, 'E pa to reo e Te Tai Rawhiti' (Your voice calling from Tai Rawhiti touches $\mathrm{me}$ ), and tells of his 'aroha' (concern) for the 'remnants of the people of this land' ('ki nga morehu o te motu nei'). Other songs remind that his teachings had changed since the days of war: 'kia ngawari noa ino nga Ture' (let the Teachings (the Laws) be gentle). One song, composed for a gathering at Wairoa on the East Coast for 1 January 1885, reminded, 'Ka kuhu au ki te ture hei matua mo te pani' (I am entered within the law, that the orphaned shall have a parent). But, in 1889, the law betrayed him.

On 28 February, he was arrested by government troops in the eastern Bay of Plenty to prevent him returning to his home, Türanga. His seizure, and the subsequent trials, created legal history. He was sent to Auckland, accompanied by his younger wife Tāmaku, and imprisoned illegally. When the Auckland Supreme Court overturned the lower court finding that he had been guilty of 'unlawful assembly', the government resorted to the Court of Appeal. This protracted saga was born out of local hysteria, manipulated by the premier, Harry Atkinson, and others. Te Kooti's most famous song, 'Pinepine te kura' (Little tiny treasure) arose from his arrest: he asked why law was abused and why 'hatred' ('te mau-a-hara') prevailed.

Finally, in 1891, the government offered the exile 600 acres at Te Wainui, near the Ōhiwa harbour, in exchange for his promise that he would not go home. Te Kooti and a group of followers set out from the King Country on 27 February 1893, but on the following day he was fatally injured when a cart, in whose shade he was sheltering, upended and fell across his back. Slowly weakening, he dragged himself to Ōhiwa, where he died on 17 April at Te Karaka on the harbour's shore. Taken to Hokianga Island, his body was stolen and interred at Maromāhue, near Ōhiwa, but was removed and hidden by his closest followers. It is not known where Te Kooti was finally buried. In death as in life, he remains elusive.

Te Kooti's only known family descend from Wētini, his eldest son, who married Ōiwia, his father's wife, in 1883. These events scarred Te Kooti, who cursed his son and his issue to the fourth generation, and they explain (in 
part) the secrecy about their ancestry with which Wētini protected his family, and which lasted until recent times

A major part of Te Kooti's significance lies in the oral predictions and sayings he left for the people and the land, as well as a large body of song texts: ninety-eight written waiata, with others remembered orally. Most of his waiata are adaptations of older songs, changed for new circumstances as songs of warning. The texts were written down by Hāmiora Aparoa, one of his three secretaries. Te Kooti's many predictions, including those for his successor, one who would be greater than he, were also recorded in writing by his secretaries, and they are cited on marae (the community house and open speaking area) today. Te Kooti has become a major figure in the historical and literary imagination of Aotearoa New Zealand, recalled for the injustice with which he was treated and his ability to rise above betrayal. As a writer, he is known for his re-formation of the texts of the Scriptures and his reconception of traditional waiata, so as to teach the conjoint principles of compassion and commitment to law.

\section{LINKS}

Te Ara: 1966 Encyclopedia of New Zealand

Te Kooti's Pennant

New Zealand Electronic Text Centre

New Zealand History on line

Dictionary of New Zealand Biography

\section{MANUSCRIPTS}

Diary kept on Wharekauri, 1867-1868, MSX-3091. Alexander Turnbull Library (ATL), Wellington.

Diary, 1869-1870. Hawke's Bay Museum, Napier.

Manuscript book of waiata (songs), 1766-1890. Compiled by Hāmiora Aparoa. MSS C-35, University of Auckland Library (AUL).

\section{BIBLIOGRAPHIES}

Binney, Judith. Redemption Songs: A Life of Te Kooti Arikirangi Te Turuki. Auckland: University of Auckland/Bridget Williams Books, 1995; revised as Redemption Songs: A Life of the Nineteenth-Century Maori Leader Te Kooti Arikirangi Te Turuki. Melbourne: Melbourne University Press, 1997; Hawai'i: Hawai'i University Press, 1997.

Binney, Judith. 'Te Kooti Arikirangi Te Turuki'. In The Dictionary of New Zealand Biography. Volume One. Ed. W. H. Oliver. Wellington: Department of Internal Affairs, 1990, pp. 462-466.

Binney, Judith. 'Te Kooti Arikirangi Te Turuki'. In The Oxford Companion to New Zealand Literature. Eds. Roger Robinson and Nelson Wattie. Melbourne: Oxford University Press, 1998, pp. 529-530. 
Binney, Judith. 'Te Kooti Arikirangi Te Turuki'. In The Oxford Dictionary of National Biography. 60 vols. Oxford: Oxford University Press, 2004. LIV: on-line edition, no pp.

Cowan, James. 'The Facts about Te Kooti'. New Zealand Railways Magazine, 1 December 1938: 17-21.

Fowler, Leo. 'A New Look at Te Kooti'. Te Ao Hou, 20-21 (November-December 1957), pp. 17-20; 18-22.

Ross, W. Hugh. Te Kooti Rikirangi, General and Prophet. Auckland: Collins, 1966.

\section{REFERENCES}

Te Pukapuka o Nga Kawenata e Waru a Te Atua me Nga Karakia Katoa a Te Haahi Ringatu. N.p: Ringatu Church, n.d.

Belich, James. The New Zealand Wars. Auckland: Auckland University Press, 1986; revised edition Auckland: Penguin, 1998.

Binney, Judith. 'Ancestral Voices: Maori Prophet Leaders'. In The Oxford Illustrated History of New Zealand. Ed. Keith Sinclair. Auckland: Oxford University Press, 1990; revised, 1996, pp. 153-184.

Binney, Judith. 'The Making of a Biography of Te Kooti Arikirangi Te Turuki'. The Journal of Pacific Studies, 20 (1996), pp. 113-122.

Binney, Judith. 'Myth and Explanation in the Ringatū Tradition. Some Aspects of the Leadership of Te Kooti Arikirangi Te Turuki and Rua Kēnana Hepetipa'. Journal of the Polynesian Society, 93 (December 1984), pp. 345-398.

Binney, Judith. 'Tom Ryan's Sketches of Te Kooti Arikirangi Te Turuki'. Turnbull Library Record, 36 (2003), pp. 35-45.

Binney, Judith. 'Te Umutaoroa: The Earth Oven of Long Cooking'. Histories, Power and Loss. Eds. Andrew Sharp and Paul McHugh. Wellington: Bridget Williams Books, 2001, pp. 147-164, 237-239.

Cooper, G. S. Letter to J. C. Richmond. 4 August 1868, Appendices to the Journal of the House of Representatives, 1868, A-15, p.13.

Cowan, James. The New Zealand Wars. 2 vols. Wellington: Government Printer, 1922-1923; revised 1955-1956; revised 1983.

Crosby, Ron. Gilbert Mair: Te Kooti's Nemesis. Auckland: Reed, 2004.

Davis, Frank. Face to Face. Auckland: Auckland War Museum, n.d. [1969].

Greenwood, William. 'Iconography of Te Kooti Rikirangi'. Journal of the Polynesian Society, 55 (March 1946), pp. 1-14.

Greenwood, William. The Upraised Hand or The Spiritual Significance of the Rise of the Ringatu Faith. Wellington: Polynesian Society, 1942; revised, 1980.

Harris, John. Letter to D. McLean. 14 April 1866, 66/587, HB4/7, Archives NZ, Wellington.

Kurei, Pāroa (Jack). Interview with Judith Binney. 15 December 1981, Ōpōtiki.

Mair, William. Letter to his brother, Robert. 12 February 1869, MS Papers 93:4, ATL.

[Mair, Gilbert, and G. A. Preece]. 'Expeditions against Te Kooti'. In The Waikato War, Together with Some Account of Te Kooti Rikirangi. Ed. John Featon. New edition revised by Captain Gilbert Mair. Auckland: Brett, 1923, pp. 165-232.

Misur, Gilda Z. 'From Prophet Cult to Established Church: The Case of the Ringatu Movement'. In Conflict and Compromise: Essays on the Maori since Colonization. Ed. I. H. Kawharu. Wellington: A. H. \& A.W. Reed, 1975; revised Auckland: Reed, 2003, pp. 97-115. 
Neich, Roger. Painted Histories: Early Maori Figurative Painting. Auckland: Auckland University Press, 1993.

Tarei, Wi. 'A Church Called Ringatu'. In Tihe Mauri Ora: Aspects of Maoritanga. Ed Michael King. [Wellington]: Methuen, 1978, pp. 60-66.

Ward, Alan. 'Documenting Maori History: The Arrest of Te Kooti Rikirangi Te Turuki, 1889', New Zealand Journal of History, XIV (April 1980), pp. 25-44.

\section{PAPERS}

Te Kooti Arikirangi's papers are scattered. Letters are held in the Alexander Turnbull Library, Wellington, the Auckland Museum Library, Archives New Zealand, Wellington, and the Onslow Collection, Guildford Muniments Room, Guildford, United Kingdom. 